\title{
Impact of Different Land Uses on the Escherichia coli Concentrations, Physical and Chemical Water Quality Parameters in a Tropical Stream
}

\author{
LING TECK YEE*, LIM SWEE WEE, LESLEY MAURICE BILUNG \& LEE NYANTI \\ Faculty of Resource Science and Technology, Universiti Malaysia Sarawak, 94300 Kota Samarahan, \\ Sarawak
}

\begin{abstract}
Rural streams are important source of water for the nearby communities. However, bacterial contamination from agriculture and human settlement may render the water unsuitable for drinking and body contact recreation. Hence, the objective of this study was to determine the impact of different land uses such as animal farming and human settlement on $E$. coli concentrations in the Serin River, a tropical stream. Samplings were conducted at 9 stations from September 2009 to March 2010. Results showed that E. coli concentrations ranged from 2,000-6,900,000 CFU/100 mL with E. coli concentrations in fish aquaculture water exceeding the WHO standard. Animal and crop farming stations showed the highest $E$. coli concentrations in the tributaries. Re-suspension from stream sediment and non-point sources such as runoff contributed to the high concentrations observed in the main river. Multiple linear regressions indicated that total suspended solids and dissolved oxygen were significant water quality parameters and they explained $68.1 \%$ of the total E. coli variations observed.
\end{abstract}

Keywords: Animal farming, agricultural run-off, total suspended solids, dissolved oxygen, tropical stream

\section{INTRODUCTION}

Microbial contamination of surface water in different parts of the world potentially limits the usage of surface water for drinking and recreational purposes. Animal farms, agriculture and domestic sources have been reported to impact the fecal bacteria concentrations downstream (Hyland et al. 2003; Pappas et al. 2008). In Canada, high fecal coliforms and E. coli counts have been reported in drainage of agricultural lands and a decrease in fecal coliforms and E. coli counts was recorded after wastewater treatment plants was upgraded with the installation of UV disinfection system (Hyland et al. 2003). In Malaysia, major source of organic contamination in Malaysian rivers were caused by continual discharge of untreated or partially treated waste from human and pigs (Muyibi et al. 2008). Animal wastes have been known to harbour pathogenic organisms that could cause water-related infectious diseases such as dysentery, cholera, gastroenteritis, salmonellosis and typhoid fever (Bitton 1994;
Maier et al. 2009). According to Mara \& Horan (2003), animal wastes such as pig's faeces could contain $E$. coli concentration of up to $10^{6} \mathrm{E}$. coli per gram of pig's faeces and daily load $E$. coli of $10^{9}$, while $E$. coli concentration in sewage and sewage effluent could harbour up to $10^{3}-10^{7}$ per $100 \mathrm{~mL}$ respectively. Thiagarajan et al. (2007) had reported that application of dairy manure on field drainage sites produced annual E. coli loads of 4.1-5.5 X $10^{10} \mathrm{CFU} / \mathrm{ha}$. The timing of manure application had effect on run-off of $E$. coli concentration where heavy rainfall can increase transport of $E$. coli from land surface to water body (Shehane et al. 2005). Faecal coliforms are commonly used as an indicator for faecal contamination in the river (Ham \& Kobori 2009). In recent years, E. coli has substituted faecal coliforms as the ideal indicator organism because it is easier to distinguish than other faecal coliforms and have a high occurrence rate in faeces (Baudisova 1997; Edberg et al. 2000; Garcia-Armisen \& Servais 2004; Tallon et al. 2005; Mishra et al. 2008). 
Serin River is a rural stream which is important as a source of drinking water, laundry and recreation by the villagers. However, human settlements and agricultural developments along rivers and streams such as animal farming and crop agriculture are potential threats to the water quality. A recent study on the Serin River water quality showed that tributary that received animal farm discharge had the lowest dissolved oxygen (DO), highest biochemical oxygen demand $\left(\mathrm{BOD}_{5}\right)$, phosphorus, ammonia-nitrogen, organic-nitrogen and copper (Ling et al. 2010). A previous $E$. coli study on this stream water only focused on a small area around animal farms discharge (Ling et al. 2006). Therefore, a more comprehensive study covering the upstream and downstream areas of this watershed with different land uses was essential. The objective of this study was to determine the impact of different land uses on the faecal bacteria concentration in Serin River and subsequently determine the physical and chemical parameters of water quality that might contribute to the variations in the bacterial count.

\section{MATERIALS \& METHODS}

\section{Study Site and Sampling}

The catchment area of Serin River is estimated to be $17 \mathrm{~km}^{2}$ and the length of the river examined was $10 \mathrm{~km}$, covering a distance from headwater R1 to downstream R5 (Figure 1). Eight samplings were conducted at nine selected stations between September 2009 and March 2010 where five stations were along the main river (R1, R2, R3, R4, R5) and the other four stations were at the tributaries, Penat River (PR), Bukah River (BR), Pam River (PR), and Bukar River (RR). In-situ measurements and water samples collection were conducted between 9:00 am and 2:00 pm during the sampling days. The river was flooded on three occasions; 7 October 2009, 19 January 2010 and 1 February 2010. Grab samples of water were collected following the Standard Methods (Clesceri et al. 1998). A 250 $\mathrm{mL}$ of sterile glass bottle was plunged neck down, against the current, into the water. The bottle was labelled, sealed with parafilm and covered with aluminium foil. Another $1 \mathrm{~L}$ polyethylene bottle was used to collect water samples for total suspended solid analysis.

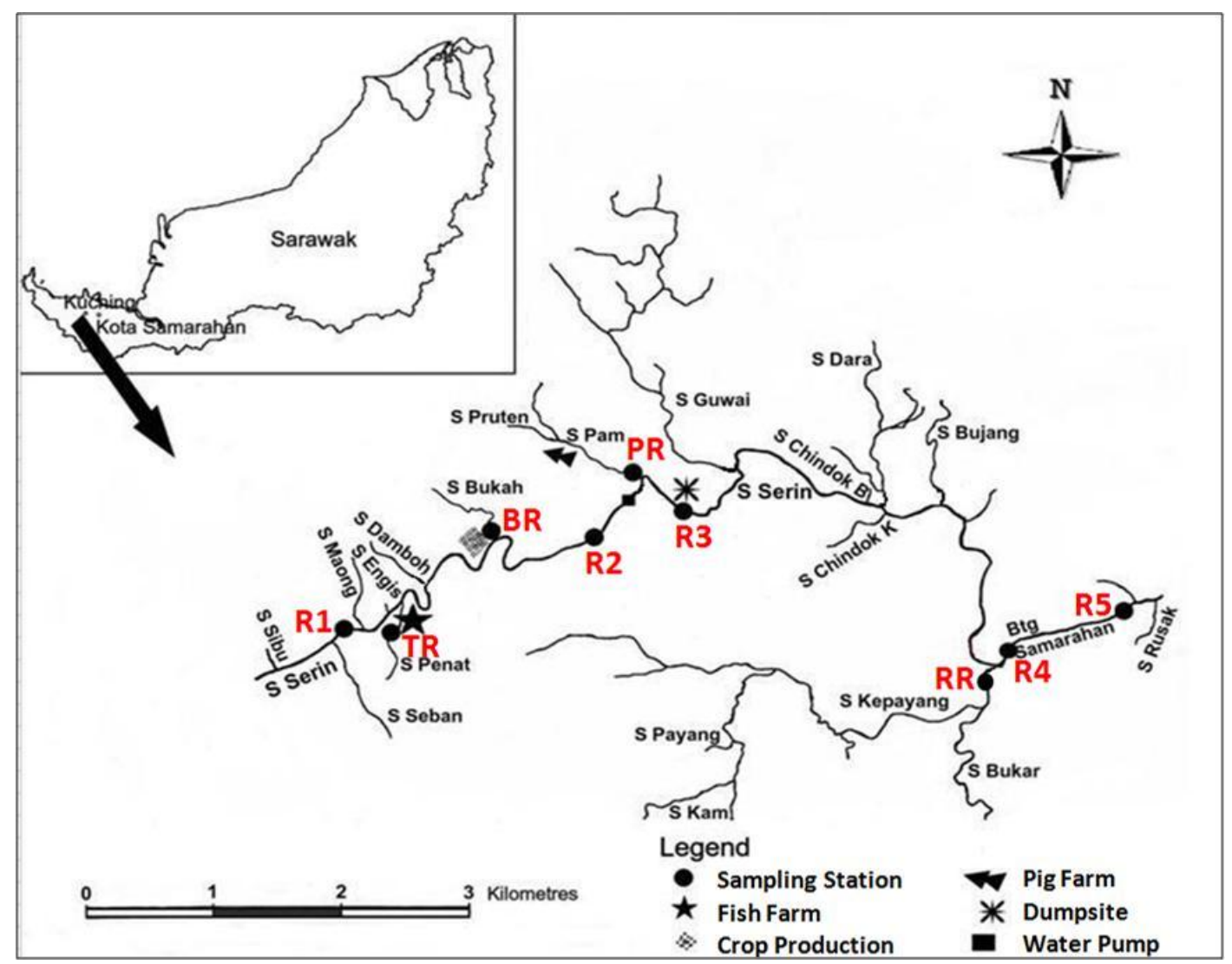

Figure 1. The location of sampling stations and human activities along the river. 
Water samples were stored in an icebox during delivery to the laboratory for sample analysis. Temperature and $\mathrm{pH}$ were measured in-situ using a pH meter (Hanna H19024) and dissolved oxygen (DO) was measured in-situ using a DO meter (Hanna H19142).

\section{Analysis of Samples}

Total suspended solids (TSS) were analyzed according to the Standard Methods (Clesceri et al. 1998). A glass-fiber filter (Whatman GF/F) was covered with labelled aluminium foil and was dried at $105^{\circ} \mathrm{C}$ in an oven (Contherm $8100)$ for two days. After drying, the glassfiber filter with the aluminium foil was cooled in a desiccator and weighed. The water sample was thoroughly mixed and $500 \mathrm{~mL}$ of the water sample was filtered with the help of a suction pump (Witeg, Germany). After filtering, the filter was kept in the aluminium foil and was dried at $105^{\circ} \mathrm{C}$ in an oven for two days. After two days, the filter was removed from the oven and was cooled in a desiccator before weighing. All samples were done in duplicate and the average values were calculated. TSS (mg/L) was calculated using equation [1]:

$$
T S S=\frac{A-B}{V}
$$

where A was the weight of filter with dried residue $(\mathrm{mg})$, B was weight of filter $(\mathrm{mg})$ and $\mathrm{V}$ was the sample volume (L).

Enumeration of $E$. coli was determined using the spread plate method (Clesceri et al. 1998). The water samples and sediment samples were diluted using $0.8 \%$ of saline solution (MERCK) where serial dilution was performed up to $10^{-3}$ in duplicate. A sterile pipette tip was used to transfer $9 \mathrm{~mL}$ of water sample into an empty sterile test tube and was labelled as $10^{\circ}$. From the $10^{\circ}$ test tube, $1 \mathrm{~mL}$ of water sample was pipetted and transferred to a test tube containing $9 \mathrm{ml}$ of saline solution. The mixture was mixed thoroughly and was labelled as $10^{-1}$. The procedure was repeated until $10^{-3}$ dilution. Duplicate set of dilutions were prepared. From the $10^{0}$ test tube, $0.1 \mathrm{~mL}$ of water sample was spread onto the surface of Eosin Methylene Blue (EMB) agar. Sterility was maintained at all times. The procedure was repeated for the other dilutions. The agar plates were left to dry at room temperature before incubation at $37^{\circ} \mathrm{C}$ for $18-24$ hours. After incubation period, the agar plates were removed from the incubator and green metallic sheen colonies were counted and recorded.

\section{Statistical Analysis}

Water Quality was classed according to the Interim National Water Quality Standards for Malaysia (INWQS) (DOE, 1994). The classification of the river for each sampling point was based on individual parameter reading. E. coli count was converted to log $\mathrm{CFU} / \mathrm{mL}$ for statistical analysis. Significant difference of each parameter of each trip was analysed using randomized complete block design to compare the differences in water quality conditions among the sampling stations at different sampling dates. Multiple linear regressions were performed to investigate the relationship between $E$. coli concentrations with physical (temperature, TSS) and chemical $(\mathrm{pH}, \mathrm{DO})$ parameters of each sampling trip using the "Enter" method. Insignificant factors were deleted in the subsequent analysis to obtain the final relationship. All data analyses were conducted using SPSS version 17.0 package.

\section{RESULTS \& DISCUSSION}

The mean water temperature ranged from $24.85^{\circ} \mathrm{C}$ to $26.88^{\circ} \mathrm{C}$ (Table 1) with the lowest at R1. Mean temperature at R1 was significantly lower than that of TR $(\mathrm{P}=0.002)$, $\mathrm{RR} \quad(\mathrm{P}=0.048), \quad \mathrm{R} 4 \quad(\mathrm{P}<0.0005)$ and $\mathrm{R} 5$ $(\mathrm{P}=0.020)$ due to the fact that the $\mathrm{R} 1$ station was constantly shaded by heavy foliage which blocked the sunlight from reaching the river water. Among the tributaries, TR showed the highest temperature as the water was kept stagnant for fish culture.

The observed mean $\mathrm{pH}$ value of all the stations varied from 6.44 to 6.95 (Table 1). Overall, all the stations had slightly acidic water condition with the most acidic in RR with a $\mathrm{pH}$ value of 6.44 . $\mathrm{R} 1$, the most upstream station recorded water with almost neutral level at $\mathrm{pH} 6.95$ which was significantly different from $\mathrm{RR} \quad(\mathrm{P}=0.022)$ and $\mathrm{R} 4$ $(\mathrm{P}=0.042) . \mathrm{pH}$ of all the stations were 
classified as Class II in accordance with INWQS.

The mean DO values ranged from 3.20 $\mathrm{mg} / \mathrm{L}$ to $7.65 \mathrm{mg} / \mathrm{L}$ with $\mathrm{R} 4$ showing the highest concentration of DO of $7.65 \mathrm{mg} / \mathrm{L}$ while PR recorded the lowest DO concentration of $3.20 \mathrm{mg} / \mathrm{L}$. Mean DO concentration of PR was significantly lower than all the main river stations and tributaries (Table 1, Figure 2a) $(\mathrm{P}<0.0005)$ due to the high oxygen demand oxidation pond effluent from animal farm shown by the study of Ling et al. (2007). Mean DO concentration measured at $\mathrm{BR}, 5.36 \mathrm{mg} / \mathrm{L}$, was also significantly different from $\mathrm{R} 4(\mathrm{P}=0.029)$. Among the main river stations, R4 showed the highest mean DO value likely due to the high inflow from the RR tributary into the main river (Figure $2 b$ ).
Compared to INWQS, PR with the lowest concentration of DO fell into Class III which required extensive treatment for water supply. Ling et al. (2006) had reported that low DO level were probably due to high microbial activity during degradation of high concentration of organic matter which explained the low DO level at PR. BR showed the second lowest DO likely due to crop agriculture activities in that tributary. TR recorded third lowest DO level because the tributary was stagnant, thus there was low reaeration. Furthermore, fish waste and uneaten feed contributed high organic matter and nutrients that exerted oxygen demand during the oxidation process. However, the DO value met the minimum required $(5 \mathrm{mg} / \mathrm{L})$ for healthy growth of fish (Lawson 1995).

Table 1. Mean and standard deviation values of temperature, $\mathrm{pH}, \mathrm{DO}, \mathrm{TSS}$, and E. coli of nine sampling stations.

\begin{tabular}{cccccc}
\hline Station & $\begin{array}{c}\text { Temperature } \\
\left({ }^{\circ} \mathrm{C}\right)\end{array}$ & $\mathrm{pH}$ & $\begin{array}{c}\text { DO } \\
(\mathrm{mg} / \mathrm{L})\end{array}$ & $\begin{array}{c}\text { TSS } \\
(\mathrm{mg} / \mathrm{L})\end{array}$ & $\begin{array}{c}\text { E. coli } \\
(\text { CFU/100mL })\end{array}$ \\
\hline R1 & $24.85 \pm 1.31^{\mathrm{a}}$ & $6.95 \pm 0.13^{\mathrm{a}}$ & $7.12 \pm 1.65^{\mathrm{bc}}$ & $13.0 \pm 14.1^{\mathrm{a}}$ & $3,246 \pm 194^{\mathrm{a}}$ \\
TR & $26.59 \pm 1.97^{\mathrm{b}}$ & $6.82 \pm 0.21^{\mathrm{ab}}$ & $5.90 \pm 1.36^{\mathrm{bc}}$ & $10.5 \pm 6.5^{\mathrm{a}}$ & $1,742 \pm 155^{\mathrm{a}}$ \\
$\mathrm{BR}$ & $26.16 \pm 1.73^{\mathrm{ab}}$ & $6.73 \pm 0.18^{\mathrm{ab}}$ & $5.36 \pm 1.32^{\mathrm{b}}$ & $31.7 \pm 35.0^{\mathrm{ab}}$ & $6,595 \pm 566^{\mathrm{a}}$ \\
R2 & $25.85 \pm 1.96^{\mathrm{ab}}$ & $6.69 \pm 0.37^{\mathrm{ab}}$ & $7.16 \pm 1.63^{\mathrm{bc}}$ & $7.7 \pm 4.7^{\mathrm{a}}$ & $2,818 \pm 185^{\mathrm{a}}$ \\
PR & $25.84 \pm 0.35^{\mathrm{ab}}$ & $6.73 \pm 0.12^{\mathrm{ab}}$ & $3.20 \pm 1.43^{\mathrm{a}}$ & $51.7 \pm 56.4^{\mathrm{b}}$ & $189,882 \pm 936^{\mathrm{b}}$ \\
R3 & $25.93 \pm 1.75^{\mathrm{ab}}$ & $6.73 \pm 0.42^{\mathrm{ab}}$ & $6.90 \pm 1.47^{\mathrm{bc}}$ & $11.1 \pm 11.9^{\mathrm{a}}$ & $3,689 \pm 154^{\mathrm{a}}$ \\
RR & $26.23 \pm 1.24^{\mathrm{b}}$ & $6.44 \pm 0.25^{\mathrm{b}}$ & $7.43 \pm 1.72^{\mathrm{c}}$ & $25.6 \pm 10.3^{\mathrm{ab}}$ & $3,129 \pm 276^{\mathrm{a}}$ \\
R4 & $26.88 \pm 0.45^{\mathrm{b}}$ & $6.48 \pm 0.22^{\mathrm{b}}$ & $7.65 \pm 1.62^{\mathrm{c}}$ & $20.6 \pm 8.9^{\mathrm{a}}$ & $5,555 \pm 197^{\mathrm{a}}$ \\
R5 & $26.26 \pm 0.98^{\mathrm{b}}$ & $6.81 \pm 0.32^{\mathrm{ab}}$ & $7.16 \pm 1.59^{\mathrm{bc}}$ & $27.1 \pm 10.9^{\mathrm{ab}}$ & $4,758 \pm 383^{\mathrm{a}}$ \\
\hline
\end{tabular}

Note: Means in the same column with the same superscripts were not significantly different at $5 \%$ level.

The mean total suspended solids of stations ranged from $7.7 \mathrm{mg} / \mathrm{L}$ to $51.7 \mathrm{mg} / \mathrm{L}$ (Table 1 ). PR tributary recorded the highest mean value of TSS and the highest variability as indicated by the high standard deviation (Fig. 3a). The high TSS observed during sampling at PR which received discharge from pig farm is in agreement with Ling et al. (2010) who reported that the tributary that received pig farm lagoon waste has a higher TSS value. High concentration of suspended solids in animal wastewater had been reported in several studies (Kinson et al. 2001; Ainon et al. 2005; Ling et al. 2007). Ling et al. (2007) reported that TSS of animal farm wastewater and oxidation pond effluent ranged from 551$333 \mathrm{mg} / \mathrm{L}$ and $21-184 \mathrm{mg} / \mathrm{L}$ respectively. The high variability was due to the high TSS sample collected on $8^{\text {th }}$ December 2009 which most likely coincided with overflow such as during daily washings or release of effluent from the animal farm oxidation ponds as shown by a previous study (Ling et al. 2008). It was reported that results of the daytime study from 8:30 am to $4: 30 \mathrm{pm}$ at that tributary showed that at $12: 30 \mathrm{pm}$ and $1: 30 \mathrm{pm}$ there were high $E$. coli count, low DO and high $\mathrm{BOD}_{5}$ attributed to increased oxidation pond discharge. Among the tributaries, BR showed second highest TSS (Figure 3d). This might be caused by agricultural activities nearby which increased sediment load brought by surface run-off to the tributary as the highest TSS ( 88 $\mathrm{mg} / \mathrm{L}$ ) at that tributary was recorded on $7^{\text {th }}$ October 2009 when the river was observed to be in flooded condition. Among the main stream stations, with the exception of station $\mathrm{R} 1$, the trend shows an increase of TSS as we 
(a)

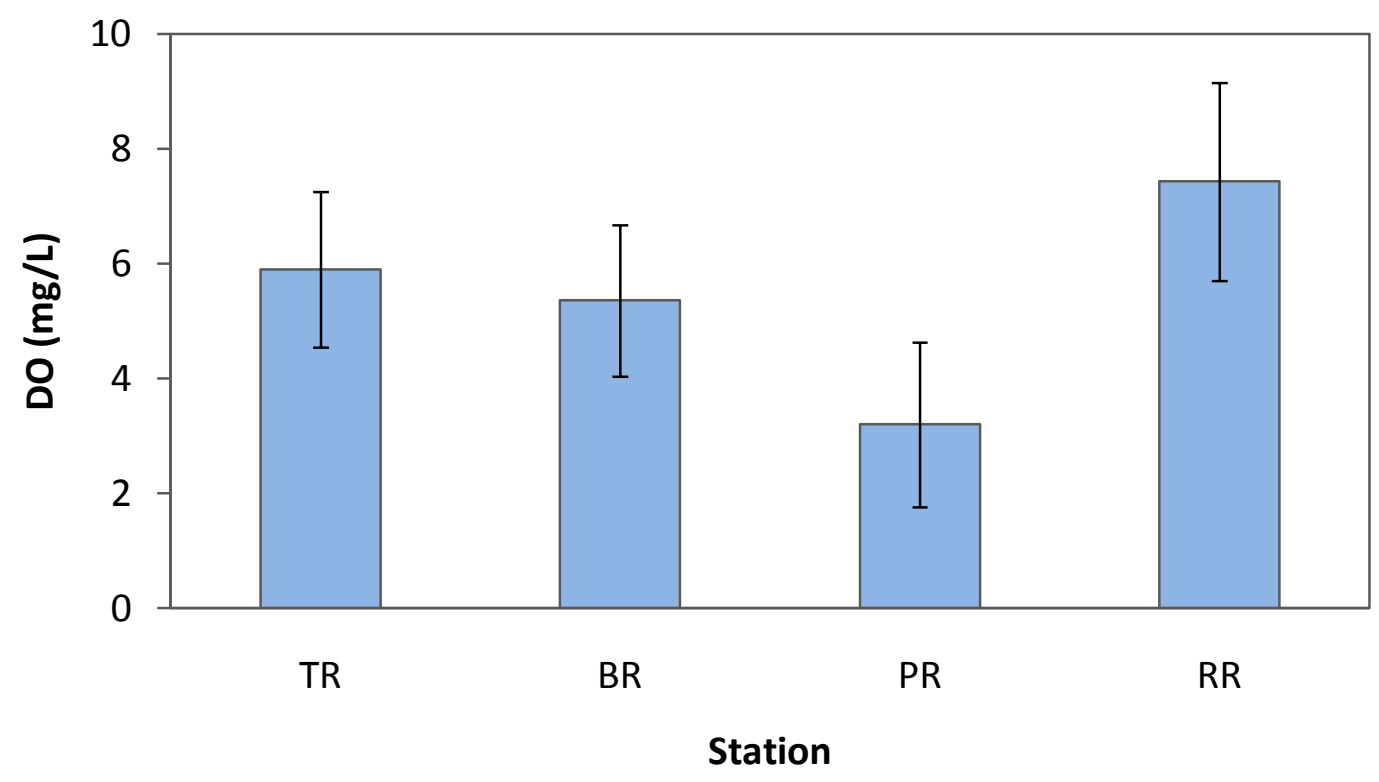

(b)

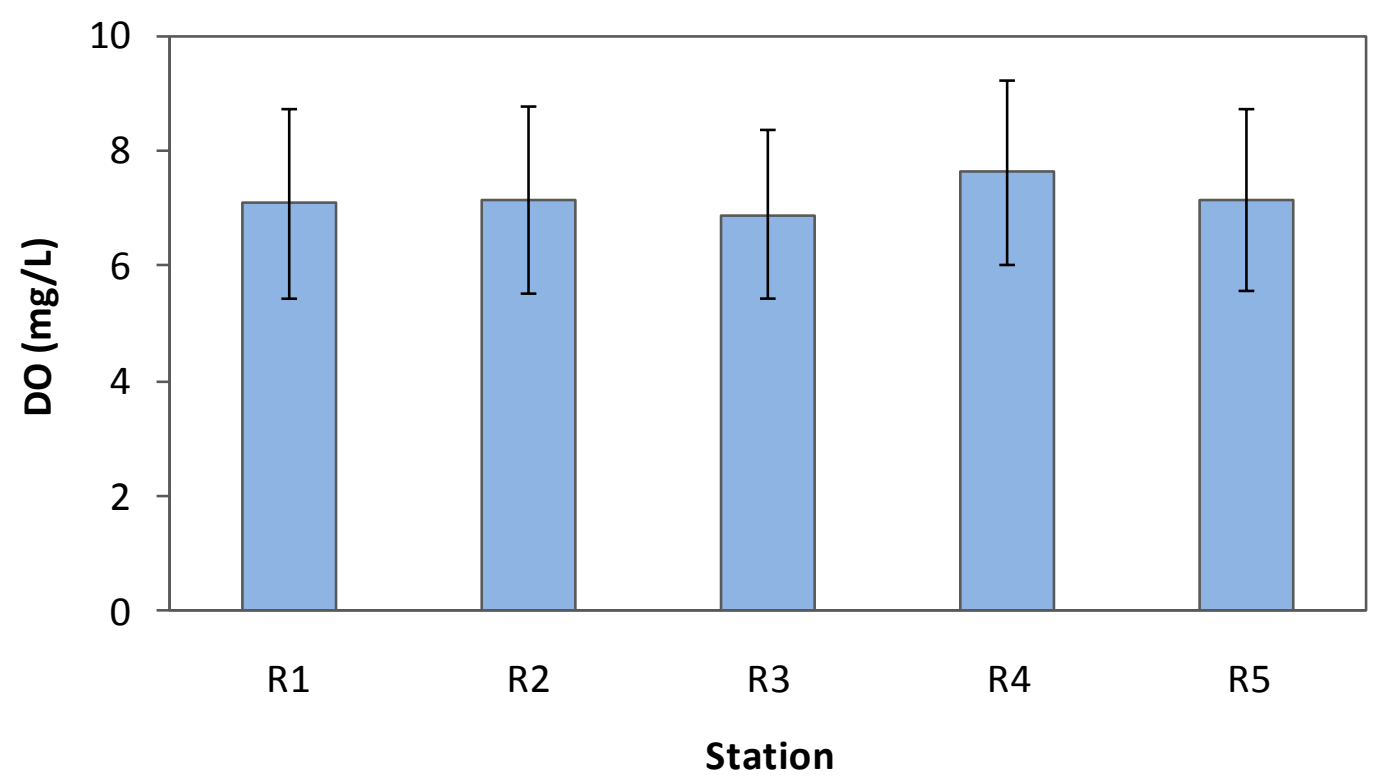

Figure 2. Dissolved oxygen of the (a) tributaries and (b) main river stations.

moved to the downstream (Figure 3b). In accordance with INWQS, TSS at PR and BR exceeded Class II $(50 \mathrm{mg} / \mathrm{L}) 25 \%$ and $50 \%$ of the time respectively while the other stations complied with Class II throughout the study period.

E. coli was detected at all stations in the sampling trips with the lowest value of 2,000 $\mathrm{CFU} / 100 \mathrm{~mL}$ at $\mathrm{R} 1$ and $\mathrm{R} 4$ when the river was flooded and R1 and R3 when the river was not flooded. Table 1 shows the concentrations of $E$. coli where station $\mathrm{PR}$ recorded the highest concentration of $189,882 \mathrm{CFU} / \mathrm{mL}$ followed by BR $(6,595 \mathrm{CFU} / 100 \mathrm{~mL})$. E. coli count at PR was significantly different from all the other stations $(\mathrm{P} \leq 0.003)$. Of the four tributaries, $\mathrm{BR}$ and PR showed higher mean values which exceeded all stations in the main river (Figure $4 a, b)$. 
(a)

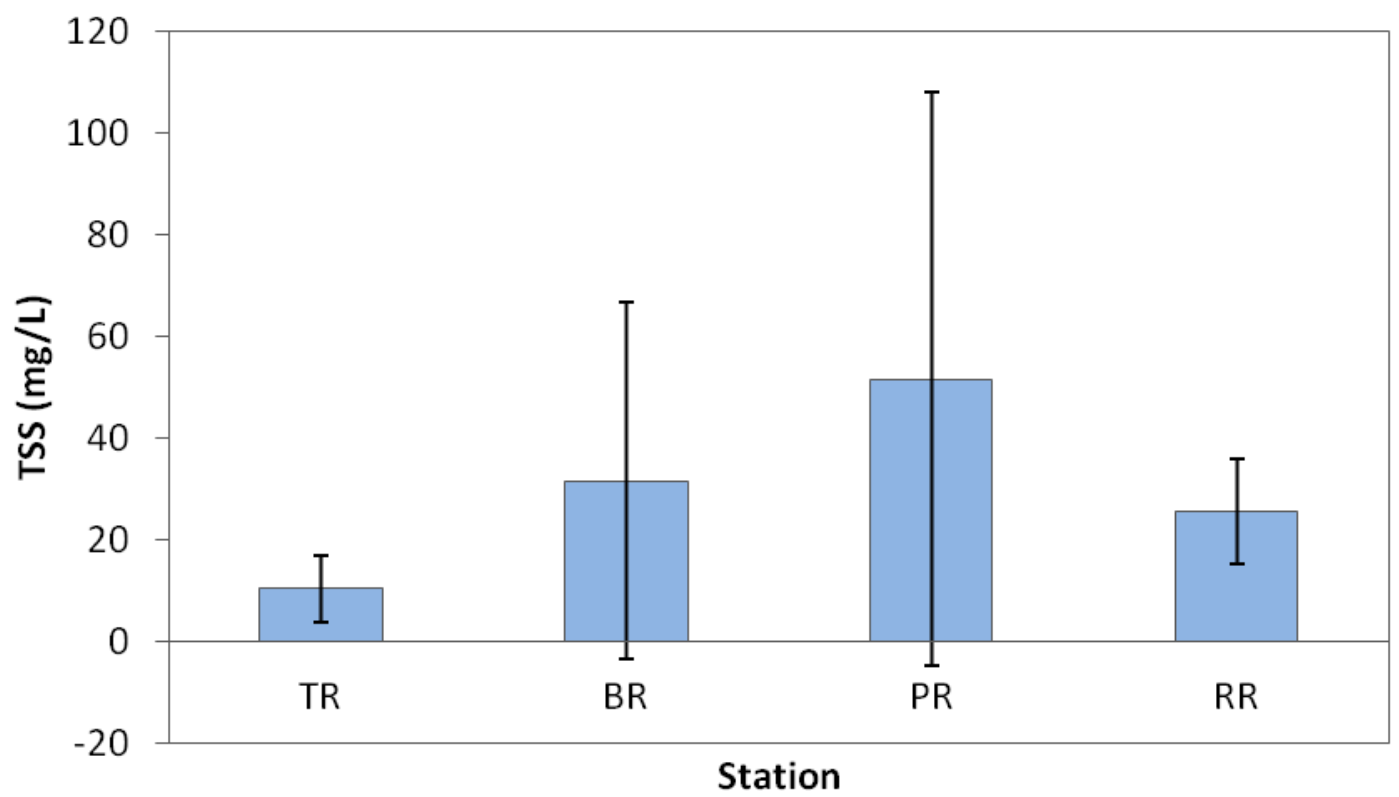

(b)

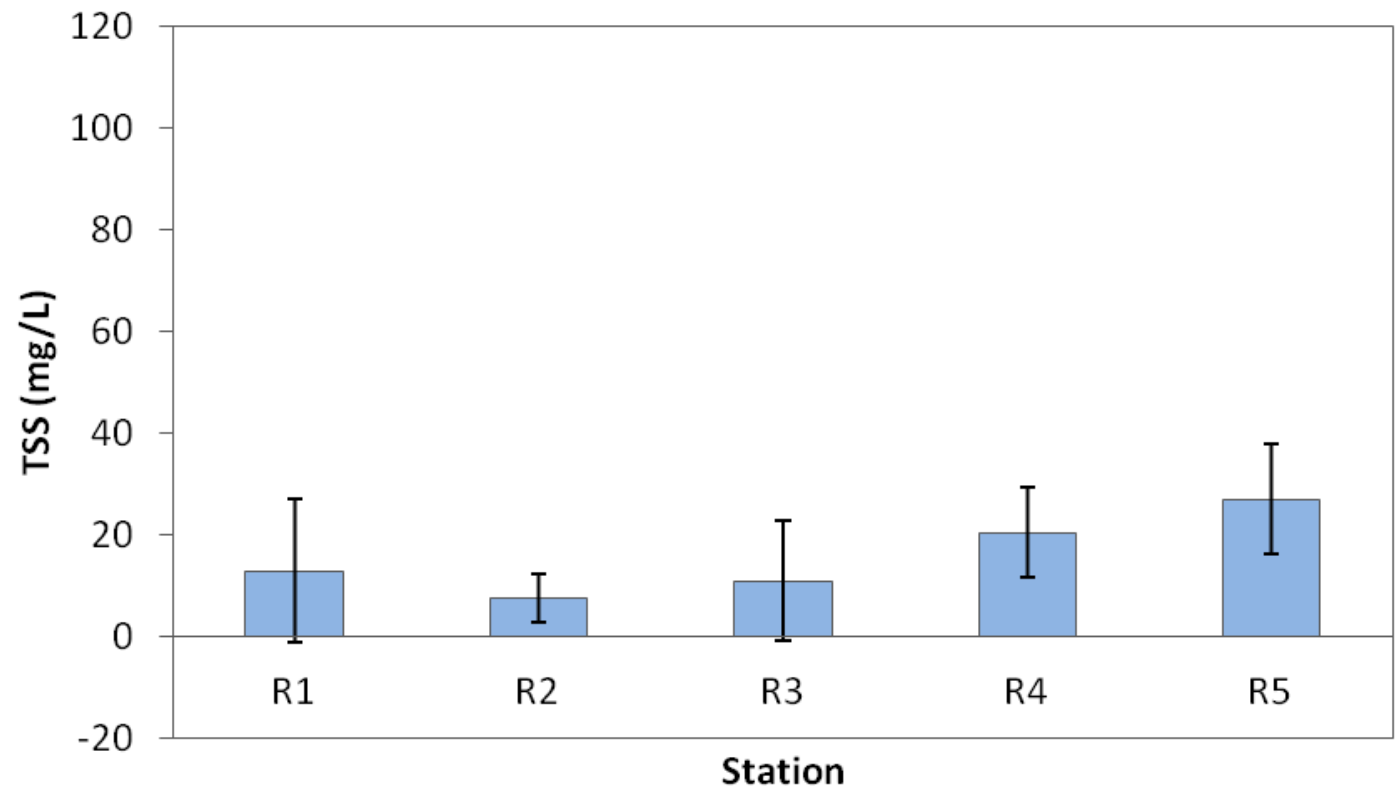

Figure 3. Total suspended solids of the (a) tributaries and (b) main river stations.

The high E. coli inflow from PR with the highest $E$. coli concentration explains the increase in main river stations as the water flows from R2 to R3. There were increases from R3 to R4 and from R4 to R5 likely due to the loading from non point-sources through runoff and resuspension in addition to contributions from upstream. Fries et al. (2006) also reported that during sampling periods dominated by runoff and resuspension, bacteria groups including E. coli showed evidence of persistence in sediment suggesting that resuspension was a significant source of bacteria to the water column. For the Serin River, sediment $E$. coli count was reported to range from $1 \times 10^{4}-1.58 \times 10^{7} \mathrm{CFU} / \mathrm{g}$ (Ling et al. 2012). The tributary used for fish aquaculture, TR, also showed the presence of E. coli exceeding the World Health Organisation standard of 1000 fecal coliforms count per $100 \mathrm{~mL}$ (WHO 1989). In accordance with INWQS of fecal coliforms count, the 
geometric mean of $E$. coli concentration at stations BR, PR, R4 and R5 with the range of 5,477-205,401 CFU/100mL exceeded Class IV (geometric mean of $5,000 \mathrm{CFU} / 100 \mathrm{~mL}$ ) and the other stations comply with Class III. In addition, E. coli concentrations at all stations exceeded the USEPA criteria for full body contact recreation which is geometric mean $E$. coli density of $126 \mathrm{CFU} / 100 \mathrm{~mL}$ (USEPA, 1986).

(a)

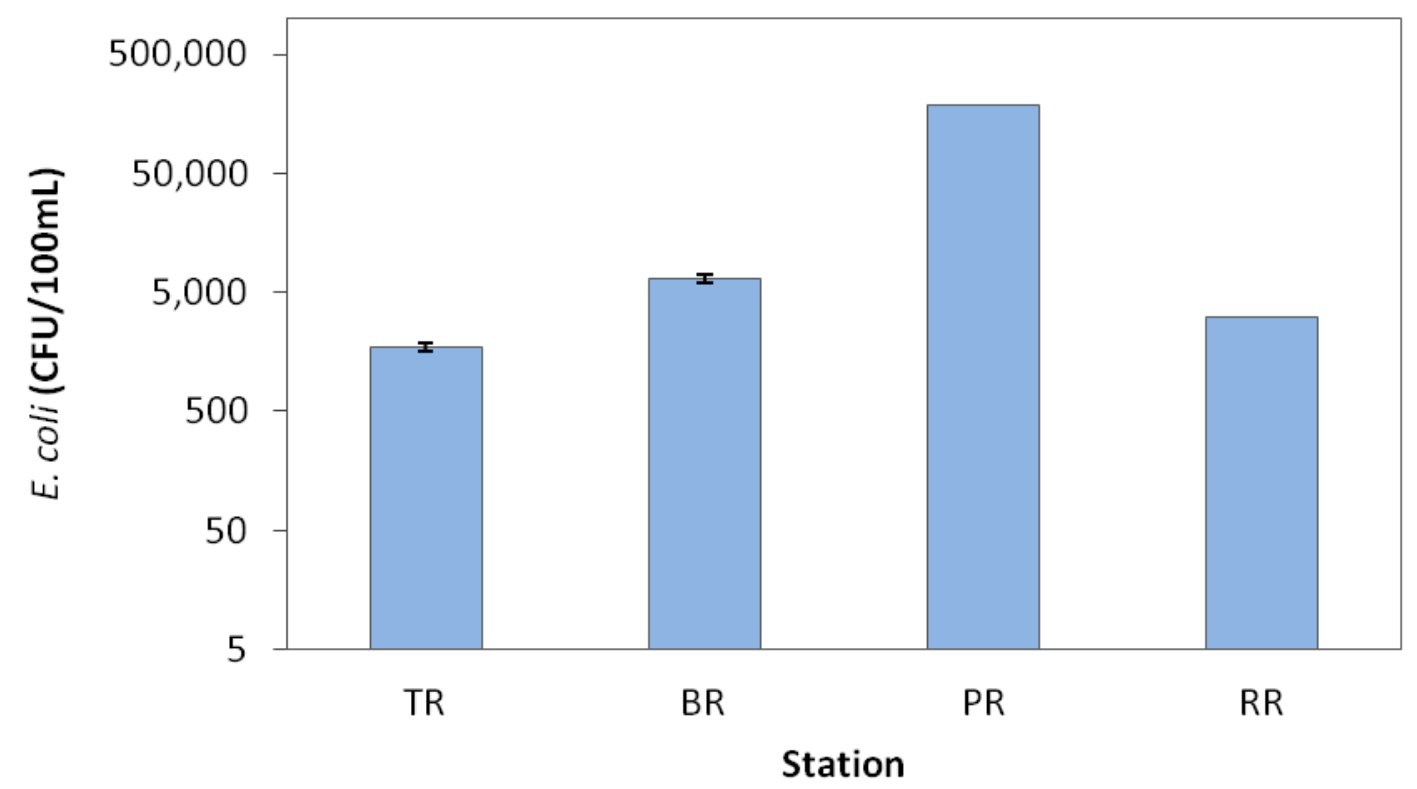

(b)

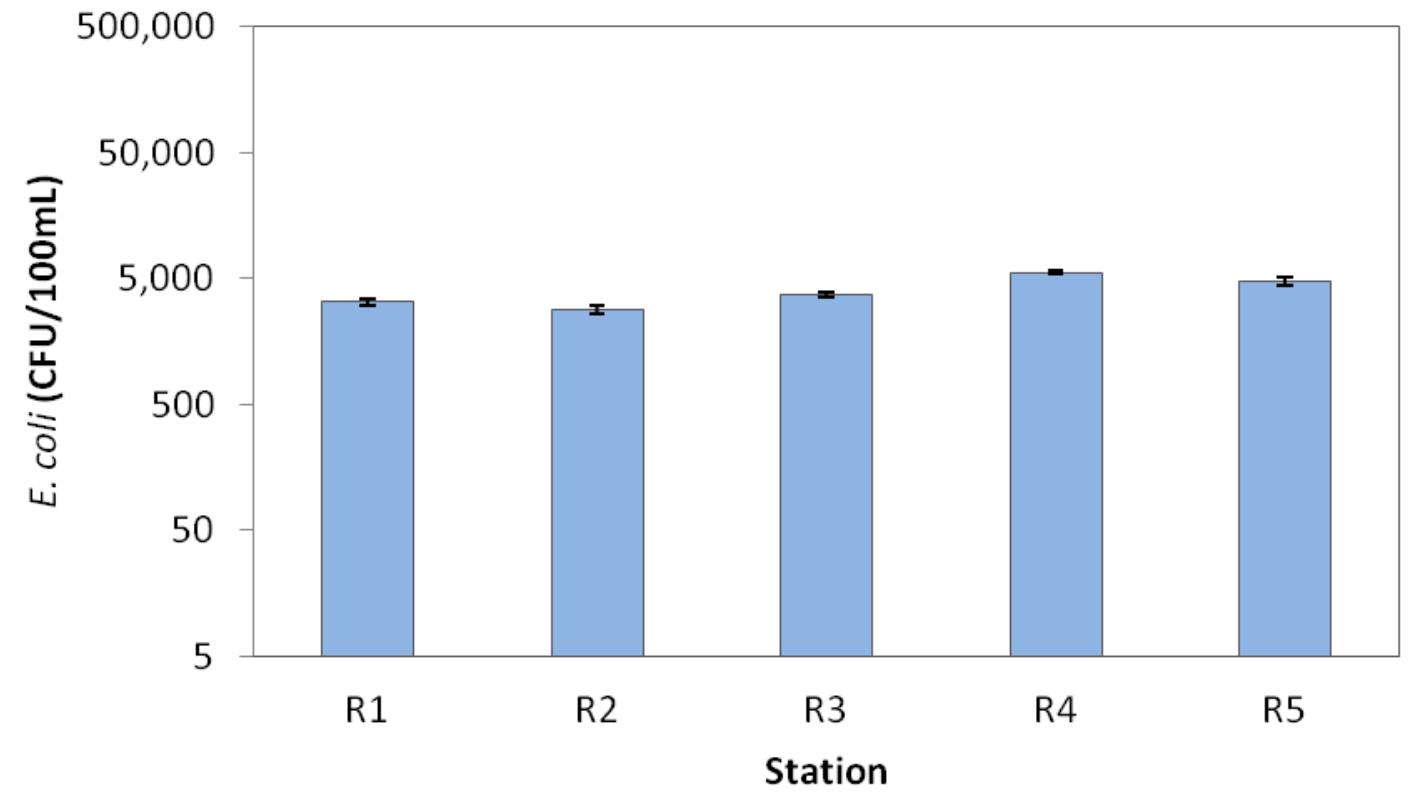

Figure 4. E. coli concentrations of the (a) tributaries and (b) main river stations.

Multiple linear regression analysis indicates that TSS $(t=7.252, \mathrm{P}<0.0005)$ and DO $(t=-$ 3.164, $\mathrm{P}=0.003)$ were significant determinants of $E$. coli concentrations explaining a total of $68.1 \%$ of the total variations. TSS and DO explains 59.4 and $8.7 \%$ of the total variations respectively. Temperature, $\mathrm{pH}$ and solar radiations were found to be insignificant $(\mathrm{P} \geq 0.115)$. The observation that TSS was significant factor likely due to the association 
of $E$. coli with sediment particles as shown by the adsorption study of Ling et al. (2002) that $E$. coli were highly adsorbed to soil particles. This observation also agreed with the report of Gannon et al. (1983) and Fries et al. (2006) that bacteria was associated with sediment particles and Fries et al. (2008) that Enterococcus sp. was correlated with turbidity in the bottom water of Neuse River Estuary. This is due to re-suspension of the sedimentassociated and runoff $E$. coli. In the present study, as DO decreased, E. coli increased. This is likely due to the inflow of $E$. coli in wastewater with low DO. This observation was also reported by Fries et al. (2008) where they observed higher concentrations of $E$. coli in hypoxic waters and sediment during resuspension period at Neuse River Estuary.

\section{CONCLUSION}

E. coli was detected at all stations throughout the sampling period with counts exceeding 2,000 CFU/100mL with the highest mean count recorded at the tributary with animal farms. Human settlement, agriculture and animal farming contributed to E. coli count in the tributaries and subsequently in the main river. There was also evidence of re-suspension and runoff contributions. TSS and DO were two significant factors that explained the variations observed.

\section{ACKNOWLEDGEMENTS}

The authors acknowledge the financial support and facilities provided by Universiti Malaysia Sarawak and the Ministry of Science, Technology and Innovation (e-ScienceFund No. 06-01-09-SF0026).

\section{REFERENCES}

Ainon, H., Mohd-Jefrin A.A., \& Ling, T.Y. (2005). Comparison of modern and traditional pig wastewater in Serian, Sarawak. Malaysian Applied Biology Journal, 34(2): 75-82.

Baudisova, D. (1997). Evaluation of Escherichia coli as the main indicator of faecal pollution. Water Science and Technology, 35(11-12): 333-336.
Bitton. G. (1994). Wastewater Microbiology. New York: Wiley-Liss, Inc. pp. 81-83, 101108.

Clesceri, L.S., Greensburg, A.E., \& Eaton, A.D. (Eds.). (1998). Standard methods for examination of water and wastewater. $20^{\text {th }}$ edition. Washington D.C.: American Public Health Association. pp. 1325.

DOE. 1994. Interim National Water Quality Standards. In: Final report on development of water quality criteria and standards for Malaysia (Phase IV-River Classification Vol. 2). Department of Environment, Ministry of Science, Technology and Environment, Malaysia.

Edberg, S.C., Rice, E.W., Karlin, R.J., \& Allen, M.J. (2000). Escherichia coli: the best biological drinking water indicator for public health protection. Journal of Applied Microbiology, 88: 106S-116S.

Fries, J.S., Characklis G.W., \& Noble, R.T. (2008). Sediment-water exchange of Vibrio sp. and fecal indicator bacteria: Implications for persistence and transport in the Neuse River Estuary, North Carolina, USA. Water Research, 42: 941-950.

Fries, J.S., Characklis, G.W., \& Noble, R.T. (2006). Attachment of fecal indicator bacteria to particles in the Neuse River Estuary, N.C. Journal of Environmental Engineering, 132(10): 1338-1345.

Gannon, J., Busse, M., \& Schillinger, J. (1983). Fecal coliform disappearance in a river impoundment. Water Research, 17: 1595-1601.

Garcia-Armisen, T. \& Servais, P. (2004). Enumeration of viable $E$. coli in rivers and wastewaters by fluorescent in situ hybridization. Journal of Microbiological Methods, 58: 269-279.

Ham, Y. \& Kobori, H. (2009). Effects of combined sewer overflow and stormwater on indicator bacteria concentrations in the Tama River due to the high population density of Tokyo Metropolitan area. Environmental Monitoring and Assessment, 152: 459-468. 
Hyland, R., Byrne, J., Selinger, B., Graham, T., Thomas, J., Townshend, I., \& Gannon, V. (2003). Spatial and temporal distribution of fecal indicator bacteria within the Oldman River Basin of Southern Alberta, Canada. Water Quality Research Journal of Canada, 38(1): 15-32.

Jamieson, R.C., Gordon, R.J., Sharples, K.E., Stratton, G.W., \& Madani, A. (2002). Movement and persistence of fecal bacteria in agricultural soils and subsurface drainage water: A review. Canadian Biosystems Engineering, 44: 1.1-1.9.

Kinson, T., Greer, T., \& Mohamad, S. (2001). Water effluent from pig farms in Sabah-A Preliminary investigation of key environmental issues. State Environment Conservation Department, Sabah. http://www.sabah.gov.my/jpas/programs/ecd -cab/background/PTS130301.pdf.

Lawson, T.B. (1995). Fundamentals of aquacultural engineering. New York: Chapman and Hall. p. 20-24.

Ling, T.Y., Liew, C.F., \& Modingin, A. (2007). Optimization of oxidation pond efficiency in animal farm wastewater treatment. Journal of Engineering Science, 3: 51-61.

Ling, T.Y., Achberger, E.C., Drapcho, C.M., \& Bengtson, R.L. (2002). Quantifying adsorption of an indicator bacteria in a soilwater system. Transactions of the ASAE, 45(3): 669-674.

Ling, T.Y., Azzyati, Z.I.M., \& Lesley, M.B. (2012). Temporal and spatial variations and decay rates of $E$. coli in river sediment. Journal of Sustainability Science and Management, 7(1): 16-22.

Ling, T.Y., Layang, H., and Apun, K. (2008). Water quality variations and decay rates of E. coli in water and sediment of the Serin River. In Proceedings of the 10th Symposium of Malaysian Society of Applied Biology, 6-8 November, Kuching, Malaysia, pp. 108-111.

Ling, T.Y., Layang, H.W., Then, Y.P., \& Apun, K. (2006). Impacts of pig farming on the water quality of Serin River, Sarawak. Sains Malaysiana, 35(1): 45-50.
Ling, T.Y., Srikaran, R., Kho, C.P., \& Nyanti, L. (2010). Organic matter, nutrients and trace metals of the Serin River. World Applied Sciences Journal, 8(4): 496-502.

Maier, R.M., Pepper, I.L., \& Gerba, C.P. (2009). Environmental microbiology. Second edition. Burlington, MA: Academic Press. pp. 137, 448, 516.

Mara, D. \& Horan, N. (2003). The Handbook of water and wastewater microbiology. London: Academic Press. pp. 101-102, 113126, 196, 611-626.

Mishra, A., Benham, B.L. \& Mostaghimi, S. (2008). Bacterial transport from agricultural lands fertilized with animal manure. Water, Air, and Soil Pollution, 189: 127-134.

Muyibi, S.A., Ambali, A.R., \& Eissa, G.S. (2008). The impact of economic development on water pollution: Trends and policy actions in Malaysia. Water Resource Management, 22: 485-508.

Pachepsky, Y.A., Sadeghi, A.M., Bradford, S.A., Shelton, D.R., Guber, A.K., \& Dao, T. (2006). Transport and fate of manure-borne pathogens: modeling perspective. Agricultural Water Management, 86: 81-92.

Pappas, E.A., Kanwar, R.S., Baker, J.L., Lorimor, J.C., \& Mickelson, S. (2008). Fecal indicator bacteria in subsurface drain water following swine manure application. Transactions of the ASABE, 51: 1567-1573.

Shehane, S.D., Harwood, V.J., Whitlock, J.E., \& Rose, J.B. (2005). The influence of rainfall on the incidence of microbial faecal indicators and the dominant sources of faecal pollution in a Florida river. Journal of Applied Microbiology, 98: 1127-1136.

Tallon, P., Magajna, B., Lofranco, C., \& Leung, K.T. (2005). Microbial indicators of faecal contamination in water: a current perspective. Water, Air, and Soil Pollution, 166: 139-166.

Thiagarajan, A., Gordon, R., Madani, A., \& Stratton, G.W. (2007). Discharge of Escherichia coli from agricultural surface and subsurface drainage water: Tillage effects. Water, Air, and Soil Pollution, 182: 3-12. 
USEPA. (1986). Ambient Water Quality Criteria for Bacteria. EPA440/5-84-002, U.S. Environmental Protection Agency, Office of Water Regulations and Standards, Criteria and Standards Div., Washington, D.C.
WHO. (1989). Health Guidelines for the Use of Wastewater in Agriculture and Aquaculture. Technical Report Series No. 778, World Health Organization, Geneva. 